\title{
Manajemen Pendistribusian Dana Zakat Pendidikan Pada Badan Amil Zakat Nasional (BAZNAS) Kabupaten Kuantan Singingi
}

\section{Management Of The Distribution Of Education Zakat Funds At The National Amil Zakat Agency (BAZNAS) In Kuantan Singingi}

\author{
Tezi Asmadia, Sri Wahyu \\ Manajemen Zakat dan Wakaf \\ Institut Agama Islam Negeri Batusangkar \\ teziasmadia@iainbatusangkar.ac.id, sriwahyu011098@gmail.com
}

Manuscript received 31 Oktober 2021, processed 02 November 2021, published 31 Desember 2021

Abstract : Management means directing, implementing, executing, controlling, regulating, effectively managing, coordinating, and creating prepared plans. The management in this research focuses on the responsibility for the distribution of zakat funds for education in BAZNAS Kuantan Singingi regency. The distribution of aducation zakat funds at BAZNAS Kuantan Singingi regency is in accordance with management functions and the procedur carried out by BAZNAS Kuantan Singingi regency started from excellent planning, organizing, implementing, and suvervising. This research is a field research in the form of qualitative descriptive method.

Keywords: BAZNAS Kuantan Singingi Regency, Distribution, Management

Abstrak: Manajemen mengandung arti mengarahkan, melaksanakan, menjalankan, mengendalikan, mengatur, mengurus dengan baik, mengkoordinasikan, membuat rencana yang telah ditetapkan. Manajemen disini menfokuskan pada manajemen pendistribusian dana zakat pendidikan di BAZNAS Kabupaten Kuantan Singingi. Manajemen pendistribusian dana zakat pendidikan di BAZNAS Kabupaten Kuantan Singingi sudah sesuai dengan fungsi-fungsi manajemen yang mana proses yang dilakukan oleh BAZNAS Kabupaten Kuantan Singingi mulai dari perencanaan, pengorganisasian, pelaksanaan dan pengawasan sudah sangat baik. Jenis penelitian yang gunakan adalah penelitian lapangan (field research) dengan metode deskriptif kualitatif.

Kata Kunci: BAZNAS Kabupaten Kuantan Singingi, Pendistribusian, Manajemen

\section{PENDAHULUAN}

Dalam konsep keadilan sosial ekonomi, terkandung suatu prinsip bahwa manusia mempunyai kesempatan yang sama untuk memperoleh kehidupan yang layak sebagai manusia, meskipun dalam kenyataannya setiap orang dibedakan oleh Tuhan tentang potensi dan berbagai kemampuan, baik fisik dan intelektual serta latar belakang profesi kehidupan ekonomi, sehingga ada yang lebih mudah mendapat rezeki dan ada yang sulit. Akibatnya masyarakat beranggotakan beragam jenis orang: ada yang kaya, ada yang miskin, ada yang terampil, ada yang tidak. Oleh karena itu, secara alamiah terjadi kesenjangan. Untuk itulah diperlukan distribusi agar kesenjangan ini dapat dipersempit.

Kata distribusi berasal dari bahasa Inggris yaitu distribute yang berarti pembagian atau penyaluran. Secara terminologi distribusi adalah penyaluran (pembagian, pengiriman) 
kepada beberapa orang atau ke beberapa tempat. Distribusi zakat mempunyai sasaran dan tujuan. Sasaran disini adalah pihak-pihak yang diperbolehkan menerima zakat, sedangkan tujuannya adalah meningkatkan kesejahteraan masyarakat dalam bidang perekonomian sehingga dapat memperkecil kelompok masyarakat yang kurang mampu, yang pada akhirnya akan meningkatkan kelompok muzakki. (Mursyidi, 2003, p. 169)

Lembaga zakat sangat berperan penting dalam masyarakat luas dengan adanya lembaga zakat pengelolaan zakat akan lebih terarah baik dari pengumulan maupun penyalurannya karena lembaga zakat sendiri akan membuat functions of management yakni POAC (planning, organizing, actuating, controlling). Sehingga dengan hal tersebut dapat mengarahkan proses dan jalannya pendistibusian. BAZNAS bertugas menghimpun dan menyalurkan zakat infak dan sedekah. Lahirnya Undang-Undang No. 23 tahun 2011 tentang Pengelolaan zakat, mengukuhkan peran BAZNAS sebagai lembaga yang berwewenang melakukan pengelolaan zakat nasional.

Salah satu BAZNAS tingkat Kab/Kota di Riau adalah BAZNAS Kabupaten Kuantan Singingi. Merupakan sebuah lembaga pengumpul zakat yang beralamat di Jl. Jend. Sudirman No. 98 Teluk Kuantan Lembaga tersebut memiliki beberapa program zakat, seperti Program kuansing makmur, kuansing sehat, kuansing cerdas, kuansing peduli, kuansing dakwah. Salah satu program BAZNAS Kabupaten Kuantan Singingi adalah program zakat untuk pendidikan dengan nama Program kuansing cerdas. Program ini merupakan bentuk empati dari pihak-pihak yang memberikan donasi kepada kaum dhuafa, dengan memfokuskan pada bantuan pendidikan kepada pelajar dan mahasiswa yang sedang menempuh pendidikan.
Tabel 1

Pendistribusian Zakat Program Kuansing Cerdas pada BAZNAS Kabupaten Kuantan Singingi.

\begin{tabular}{|c|l|l|}
\hline Tahun & $\begin{array}{l}\text { Pendistribusian } \\
\text { Zakat } \\
\text { Pendidikan }\end{array}$ & $\begin{array}{l}\text { Pengumpulan } \\
\text { Zakat }\end{array}$ \\
\hline 2018 & $\begin{array}{l}\text { Rp. } \\
1.929 .000 .000\end{array}$ & $\begin{array}{l}\text { Rp. } \\
6.241 .960 .208\end{array}$ \\
\hline 2019 & $\begin{array}{l}\text { Rp. } \\
2.238 .061 .000\end{array}$ & $\begin{array}{l}\text { Rp. } \\
7.285 .319 .009\end{array}$ \\
\hline 2020 & $\begin{array}{l}\text { Rp. } \\
2.945 .530 .200\end{array}$ & $\begin{array}{l}\text { Rp. } \\
8.713 .917 .692\end{array}$ \\
\hline
\end{tabular}

Sumber: Laporan Pendistribusian Zakat BAZNAS Kabupaten Kuantan singingi Tahun 2018 Sampai 2020

Dari table diatas terlihat bahwa dari tahun 2018 sampai tahun 2020 pengumpulan dan pendistribusian dana zakat oleh BAZNAS Kabupaten Kuantan Singingi terus meningkat Begitu juga dengan dana zakat di bidang pendidikan yang juga terus meningkat di tiga tahun terakhir. Dengan adanya peningkatan setiap tahunnya baik itu dari pengumpulan dan pendistribusian zakat maka ini akan nada kaitannnya dengan manajmen yang dilakukan oleh pihak BAZNAS Kabuaten Kuantan Singingi.

\section{METODE PENELITIAN}

Penelitian yang dilakukan oleh peneliti adalah penelitian lapangan atau field research. Metode penelitian yang digunakan adalah metode deskriptif kualitatif. Penelitian ini dilakukan di kantor Badan Amil Zakat Nasional (BAZNAS) Kabupaten Kuantan Singingi Jl. Jend Sudirman No. 98 Teluk Kuantan, 29562 (Samping Pasar Rakyat).

Dalam Penelitisn ini peneliti menggunakan dua sumber data, yaitu: 
1. Sumber Data Primer

Adapun yang menjadi sumber data primer adalah Peneliti melakukan wawancara dengan pegawai (Pimpinan, Staf keuangan dan Staf Pendistribusian zakat) di BAZNAS Kabupaten Kuantan Singingi.

2. Sumber Data Sekunder

Pada sumber data sekunder ini peneliti memerlukan Standar Operasional Prosedur (SOP) dari BAZNAS Kabupaten Kuantan Singingi serta wawancara dari mustahik dan dokumen terkait sebagai pendukung penelitian ini.

Analisis data adalah proses mencari dan menyusun secara sistematis data yang diperoleh dari hasil wawancara, catatan lapangan, dan dokumentasi. Maka penulis menganalisis dengan cara:

1. Reduksi Data

Mereduksi data berarti merangkum, memilih datayang diperlukan sehingga menghasilkan informasi yang memfokuskan pada hal-hal yang penting, bermakna, dan mudah dalam penarikan kesimpulan.

2. Menyajikan Data

Penyajian data bisa dilakukan dalam bentuk uraian singkat, yang dapat disususn secara sistematis dan mudah dipahami sehingga memberikan kemungkinan menghasilkan kesimpulan yang nantinya berupa teks naratif.

3. Menarik Kesimpulan

Peneliti memeriksa keabsahan data yang diperoleh dari hasil observasi, indepth interview, dan dokumentasi dengan membandingkan hasil-hasil tersebut sehingga diperoleh data yang valid, agar hasil temuan lebih kuat.

\section{HASIL PENELITIAN DAN PEMBAHASAN}

Manajemen berasal dari kata manage yang artinya mengatur. sedangkan secara terminologis para pakar mendefinisikan manajemen secara beragam, diantaranya menurut Malayu S. P. Hasibuan adalah: Manajemen merupakan suatu proses yang khas yang terdiri dari tindakan-tindakan perencanaan, pengorganisasian, penggerakan dan pengendalian yang dilakukan untuk menentukan serta mencapai sasaran-sasaran yang telah ditentukan melalui pemanfaatan sumber daya manusia dan sumber-sumber lainnya. (Nisa, 2016, p. 23)

Kata distribusi berasal dari bahasa Inggris yaitu distribute yang berarti pembagian atau penyaluran. Secara terminologi distribusi adalah penyaluran (pembagian, pengiriman) kepada beberapa orang atau ke beberapa tempat.

Distribusi zakat mempunyai sasaran dan tujuan. Sasaran disisni adalah pihak-pihak yang diperbolehkan menerima zakat, sedangkan tujuannya adalah meningkatkan kesejahteraan masyarakat dalam bidang perekonomian sehingga dapat memperkecil kelompok masyarakat yang kurang mampu, yang pada akhirnya akan meningkatkan kelompok muzakki. (Mursyidi, akuntansi zakat kontempor, 2003, p. 169)

Maka, pendistribusian zakat merupakan penyaluran atau pembagian dana zakat kepada mereka yang berhak. Dalam undang undang No 23 tahu 2011 tentang pengelolaan zakat pasal 25 mengatakan bahwa "zakat wajib didistribusikan kepada mustahik sesuai dengan syariah Islam" sedangkan pasal 26 mengatakan bahwa "pendistribusian zakat sebagai mana yang dimaksud dalam pasal 25, dilakukan berdasarkan skala prioritas dengan memperhatikan prinsip pemerataan, keadilan 
dan kewilayahan." (Undang-undnag no 23 tahun 2011 tentang pengelolaan zakat)

Dalam undang-undang No 23 tahun 2011 menjelaskan bahwa pendistribusian zakat dilakukan berdasarkan skala proiritas dengan memperhatikan prinsip pemerataan, keadilan dan kewilayahan yang terdapat di pasal 26 . Bentuk inovasi distribusi dikategorikan dalam empat bentuk berikut: (Wiradifa, 2017, p. 4)

a. Distribusi bersifat konsumtif tradisional, yaitu dibagikan kepada mustabiq untuk dimanfaatkan secara langsung, seperti zakat fitrah atau zakat mal yang dibagikan kepada para korban bencana alam.

b. Distribusi bersifat konsumtif kreatif, yaitu diwujudkan dalam bentuk lain dari barangnya semula seperti diberikan dalam bentuk alat-alat sekolah atau beasiswa.

c. Distribusi bersifat produktif ,tradisional, diberikan dalam bentuk barang-barang yang produktif seperti kambing, sapi dan lainnya. Pemberian dalam bentuk ini akan menciptakan suatu usaha yang membuka lapangan kerja bagi fakir miskin.

d. Distribusi dalam bentuk produktif kreatif, yaitu diwujudkan dalam bentuk permodalan baik untuk pembangunan proyek sosial atau penambahan modal pedagang pengusaha kecil.

Pengelolah zakat oleh lembaga pengelola zakat, apalagi yang memiliki kekuatan hukum formal akan memiliki beberapa keuntungan, antara lain untuk menjain kepastian dan disiplin pembayar zakat, menjaga perasaan rendah diri para mustabiq zakat apabila berhadapan langsung untuk menerima zakat dari para mizakki, mencapai efisien efektifitas, serta sasaran yang tepat dalam menggunakan harta zakat menurut skala prioritas yang ada pada suatu tempat, memperlihatkan syiar Islam dalam semangat penyelenggaraan pemerintahan yang Islami. Jika zakat diserahkan langsung dari muгak,ki kepada mustahiq meskipun secara hukum syariah adalah sah, akan tetapi disamping akan terabaikannya hal-hal tersebut diatas, juga hikmah dan fungsi zakat, terutama yang berkaitan dengan kesejahteraan umat akan sulit diwujudkan. (Wiradifa, 2017, p. 4)

\section{Perencanaan Pendistribusian Zakat Program Pendidikan}

Perencanaan dalam pendistribusian zakat tentunya harus sesuai dengan syariat Islam yaitu kepada hasnaf 8. BAZNAS Kabupaten Kuantan Singingi memiliki 5 program kerja yaitu program kuansing sehat, kuansing makmur, kuansing cerdas, kuansing peduli, dan kuansing dakwah. Pada program kuansing cerdas yang mana pada program ini menyangkut penyaluran dana zakat untuk pendidikan bagi masyarakat yang tidak mampu. BAZNAS mendata, memverifikasi, menentukan dan menetapkan berapa orang yang mesti dibantu, jenis bantuan apa yang akan diberikan kemudian berapa indeknya.

Sebelum melaksanakan pendistribusian pengurus BAZNAS Kabupaten Kuantan Singingi melakukan perencanaan seperti:

a. Merencanakan rapat pendistribusian zakat pendidikan

Perencanaan ini berguna untuk membahas tentang realisasi pendistribusian dana zakat untuk pendidikan. Dalam rapat yang dilakukan oleh BAZNAS dibagi dua yaitu:

1) Rapat Internal

Rapat ini dilakukan oleh pengurus BAZNAS Kabupaten Kuantan Singingi yaitu ketua, wakil ketua serta pelaksana.

2) Rapat Eksternal

Rapat ini dengan OPZ yang ada di tingkat kecamata Kabupaten Kuantan Singingi. Karna nantinya BAZNAS akan dibantu dalam pengumpulan data mustabiq melalui OPZ. 
b. Merencanakan kriteria mustabiq

Pada program kuansing cerdas ini BAZNAS telah menetapkan kriteria bagi mustabiq yang telah ditetapkan dalam Standar Operasional Prosedur (SOP), yaitu:

1) Program beasiswa tingkat $S D, S M P$

Orang tua pelajar termasuk dalam kategori fakir atau miskin yang dibuktukan dengan surat keterangan tidak mampu dari desa/kelurahan. Berdomisili di Kabupaten Kuantan Singingi yang dibuktikan dengan kartu tanda penduduk (KTP) dan kartu keluarga (KK) Kabupaten Kuantan Singingi. Diusulkan oleh kepala sekolah secara kolektif atas nama pelajar yang bersangkutan.

2) Program mahasiswa

Mahasiswa tersebut sedang menyelesaikan skripsi pada tahun berjalan. Membuat surat permohonan yang diajukan kepada ketua BAZNAS. Tercatat sebagai penduduk di Kabupaten Kuantan Singingi yang dibuktikan dengan kartu tanda penduduk (KTP) dan kartu keluarga (KK) Kabupaten Kuantan Singingi. Adanya surat keterangan kurang mampu dari desa/kelurahan. Surat keterangan aktif dari dekan fakultas. Fotocopy kartu tanda mahasiswa sebanyak 1 lembar dan proposal yang sudah disetujui oleh pihak kampus.

3) Bantuan pendidikan luar negeri

Membuat surat permohonan yang diajukan kepada ketua BAZNAS Kabupaten Kuantan Singingi. Tercatat sebagai penduduk di Kabupaten Kuantan Singingi yang dibuktikan dengan kartu tanda penduduk (KTP) dan kartu keluarga (KK) Kabupaten Kuantan Singingi. Adanya surat keterangan kurang mampu dari desa/kelurahan. Serta keterangan bukti lulus dari perguruan tinggi yang dimasuki.

c. Kuota jumlah penerimaan mustabiq

Dalam penentuan kuota pada program kuansing cerdas ini bersadasarkan rencana anggaran kerja tahunan (RAKT) ini dibuat berdasarkan target pengumpulan tiap tahunnya.

d. Merencanakan sumber data calon mustabiq

Rencana BAZNAS untuk mendapatkan data calon muatahiq yaitu dengan cara berkoordinasi dengan UPZUPZ yang berada ditingkat kecamatan/kemenag dan melalui kepala sekolah/madrasah dan mengirimkan soft copy data usulan penerima bantuan tersebut ke BAZNAS Kabupaten Kuantan Singingi.

\section{Pegorganisasian Pendistribusian Zakat Pendidikan}

Setelah penyusunan perencanaan, selanjudnya yang perlu disusun adalah pengorgnisanian dengan maksud mendayagunakan segala sumber daya manusia yang ada dalam lingkungan organisasi. Pengorganisasian merupakan sebuah proses membentuk struktur dan hubungan yang memungkinkan para pengurus, pegawai dan relawan dalam menjalankan apa yang telah disusun dalam perencanaan guna mencapai tujuan dan target-target program pendidikan. Oleh karena itu dianggap perlu dalam pengorganisasian ini membicaraka tentang struktur organisasi terkait hubungan penyesuaian antara perencanaan, pengawasan, dan pengarahan dari setiap fungsi yang terdapat dalam organisasi. (Salim, 2020, p. 62) 
a. Langkah-langkah dalampengorganisasian

1) Perumusan kerja

Sebagai dasar utama dari sebuah penyusunan organisasi, pekerjaan yang ingin dicapai harus dirumuskan dengan jelas dan disesuaikan dengan sumber daya yang ada pada sebuah organisasi. Penentuan bidang, ruang lingkup sasaran, keterampilan dan peralatan yang diperlukan dalam proses pencapaiannya. Dalam proses perumusan kerja diketahui ukuran besar kecilnya pekerjaan yang akan dilakukan oleh BAZNAS Kabupaten Kuantan Singingi. Dalam program kuansing cerdas BAZNAS Kabupaten Kuantan Singingi merumuskan siapa saja pegawai yang memiliki kopetensi dalam bidangnya. Dengan perumusan kerja yang sesuai dengan sumber daya manusia yang ada maka akan meningkatkan kemampuan BAZNAS Kabupaten Kuantan Singingi dalam bekerja.

2) Penetapan tugas pokok

Setelah rumusan kerja terbentuk dan disesuaikan antara kebutuhan kerja dan sumber daya manusia yang ada dalam lingkungan BAZNAS Kabupaten Kuantan Singingi kemudian ditentukan tugas pokok. Tugas pokok merupakan penentuan orientasi kerja, dimana tugas yang dikerjakan tahu batasn-batasan dan target keberhasilan yang ingir dicapai organisasi. Tugas pokok ini dilakukan sesuai dengan kebutuhan program yang dijalankan oleh BAZNAS Kabupaten Kuantan Singingi.

3) Perincian kegiatan

Setelah tugas pokok terbentuk maka yang harus dilakukan adalah menjabarkan kegiatan yang harus dilakukan. Membuat daftar acuan dan rincian kerja secara operasional dengan mudah dikerjakan oleh pegawai. Rincian kegiatan ini akan menjadi sebuah panduan bagi pengguna dalam kegiatan rutinitas program kuansing cerdas yang dijalankan oleh BAZNAS Kabupaten Kuantan Singingi. Kegiatan yang terperinci akan menambah fokus kerja yang dilakukan pegawai yang ada di lingkungan BAZNAS Kabupaten Kuantan Singingi.

b. Pegelompokan kegiatan

Di dalam realisasi program kuansing cerdas erat kaitannya dengan tugas-tugas pokok yang dilakukan oleh pegawai. Pengelomokan kegiatan ini disusun supaya sistematis dan jelas. Pengelompokan ini dalam ilmu organisasi disebut dengan nama fungsi. Hal tersebut dilakukan supaya menambah strategi kerja di lingkungan BAZNAS Kabupaten Kuantan Singingi.

c. Staffing

Untuk melakukan Staffing atau lebih dikenal dengan pengisisan personalia sesuai dengan bakat dan keahlian sumber daya manusia yang dimiliki BAZNAS Kabupaten Kuantan Singingi maka sangat perlu dilakukannya staffing supaya pekerjaan segera cepat selesai dan memiliki hasil yang maksimal. Kemampuan personal sangat dibutuhkan dalam organisasi yaitu keahlian yang dimiliki oleh setiap pegawai BAZNAS Kabupaten Kuantan Singingi.

d. Fasilitas

Tindakan yang tidak kalah penting dalam pengorganisasian adalah memberi fasilitas terhadap semua bagian yang diperlukan berupa perlengkapan dan peralatan organisasi, baik berupa 
financial, material, maupun lainnya. Prinsip BAZNAS Kabupaten Kuantan Singingi ialah memberikan fasilitas sesuai dengan tugas, tanggung jawab dan tujuan program, dalam hal ini adalah program kuansing cerdas.

\section{Pelaksanaan Pendistribusian Zakat}

\section{Pendidikan}

Dari segi pelaksanaan program kuansing cerdas sudah teraktualisasi dengan baik. Penggerakan atau pelaksanaan tindakan ini mulai dari penghimpunan sampai dengan penyaluran manfaat dana zakat.

a. Pelaksanaan penghimpunan dana zakat

Ini merupakan pengumpulan dana zakat dari para muzakki atau donator kepada organisasi amil zakat untuk kemudian disalurkan kepada yang berhak menerima manfaat dana zakat (mustabik) sesuai dengan syariat Islam. Kegiatan pengumpulan dana zakat ini adalah dengan cara menerima atau mengambil langsung dari muzakki dan donator atas dasar pemberitahuan dari murakeki.

Dalam penghimpunan atau pengumpulan dana zakat BAZNAS melakukan pendekatan-pendekatan kepada pihak yang dikategorikan sebagai calon muzakei mulai dari intansi sehingga pembentukan UPZ-UPZ yang mana nantinya UPZ tersebut akan membantu dalam pengumpulan dana zakat tersebut.

b. Pelaksanaan penyaluran manfaat dana zakat

Penyaluran merupakan kegiatan membagikan sejumlah harta atau manfaat dari zakat yang sudah terhimpun oleh BAZNAS Kabupaten Kuantan Singingi untuk selanjudya diberikan kepada mustabik. Dalam hal ini manfaat dana zakat disalurkan pada program kuansing cerdas.

pelaksanaan pendistribusian dana zakat meliputi waktu dan tempat penyerahan serta bagaimana prosedur penyerahannya. Setelah ditetapkannya mustabiq penerima zakat pendidikan tersebut maka BAZNAS akan melakukan penyerahan dana zakat untuk SD, SMP dari BAZNAS Kabupaten Kuantan Singingi Ke masing-masing Kecamatan yang ada di Kabupaten Kuantan Singingi Melalui unit pengumpul zakat (UPZ). Untuk pendidikan ini dengan sistem penyaluran yang cukup baik maka ini diharapkan sudah bisa meringankan beban dan dapat membantu siswa yang kurang mampu dalam pendidikannya.

Tahapan setelah perencanaan, pengorganisasian adalah pelaksanaan. Pada program kuansing cerdas BAZNAS Kabupaten Kuantan Singingi yang dilakukan pada tahap pelaksanaan dan model seleksi tidak jauh berbeda dengan program beasiswa lainnya. Untuk dapat menerima besiswa program kuansing cerdas, calon penerima beasiswa harus melewati tahapan seleksi yang telah diberikan oleh pihak BAZNAS Kabupaten Kuantan Singingi. Model tahapan yang dimaksud seperti berikut:

1) Tahapan administrasi atau pemberkasan. Pada tahap ini siswa diberikan syarat dan ketentuan penerima beasiswa dengan cara melalui pihak kepala sekolah kemudian didampingi oleh wali kelas masing-masing siswa. Hal ini dilakukan supaya regulasi yang dilakukan jelas dan diketahui semua 
pihak yang terlibat dalam program kuansing cerdas.

2) Seleksi administrasi. Seleksi ini dimaksud untuk menyaring berkas yang sudah dilengkapi oleh calon peerima beasiswa untuk kemudian dapat dilanjudkan pada tahap berikutnya.Tahap ini dilakukan untuk pengecekan berkas yang terkumpul dari calon penerima beasiswa. Seleksi administrasi ini berisikan formulir pendaftaran dan berkas berkas pendukung lainnya.

3) Verivikasi mustabik. Setelah tahap seleksi administasi diumumkan bagi siswa yang lolos seleksi berkas. Maka tahap selanjudnya akan dilakukan verifikasi mustabik, tujuannya adalah untuk memastikan bahwa siswa atau(mustabik) tersebut benar-benar layak untuk mendapatkan beasiswa yang diberikan oleh BAZNAS Kabupaten Kuantan Singingi.

4) Pengumuman. Tahap ini merupakan tahap terakhir untuk penetapan siswa yang tercantum dalam pengumuman lolos rangkaian seleksi untuk dapat sebagai mustabik dan berhak pemperoleh beasiswa program kuansing cerdas.

Penggerakan atau pelaksanaan adalah seluruh proses pemberian ,oivasi kerja kepada pada bawahan sedemikian rupa, sehingga mereka mampu bekerja dengan iklas demi tercapainya tujuan organisasi dengan efisien dan ekonomis. Jadi dalam proses pelaksanaan program kuansing cerdas BAZNAS Kabupaten Kuantan Singingi telah menerapkan fungsi pelaksanaan dalam manajemen pendistribusian zakat.

\section{Pengawasan Program Kuansing Cerdas}

Pengawasan sangat penting untuk dialankan ketika proses perencanaan, pengorganisasian, dan pelaksanaan maka perlu dilakukan selanjudnya adalah pengawasan. Pengawasan dilakukan untuk menjamin langkah pengambilan keputusan sudah sesuai dengan rencana yang telah ditentukan awal.

Pengawasan dilakukan untuk mencegah deviasi dalam operasional suatu rencana, sehingga berbagai kegiatan yang sedang berlangsung dapat berjalan dengan baik. Apabila dalam pengawasan tidak dilaksanakan dengan disiplin maka rencana yang sudah ditetapkan tidak akan terarah bahkan akan jauh dari yang diharapkan. Perlu dipahami bahwa pengawasan merupakan fungsi manajemen terakhir dalam kegiatan manajemen yang dimaksudkan supaya tujuan yang telah ditetapkan organisasi dapat tercapai sesuia rencana. pengawasan yang dilakukan oleh pihak BAZNAS Kabupaten Kuantan Singingi pada program kuansing cerdas sudah optimal dilakukan.

\section{Faktor Pendukung Dan Penghambat} Pendistribusian Zakat Di BAZNAS Kabupaten Kuantan Singingi

Pengelolaan zakat secara professional memerlukan tenaga yang terampil, menguasai masalah-masalah yang berhubungan dengan zakat, seperti muzakki, nisab, hawl dan mustahiq zakat. Begitu pula sulit dibayangkan apabila pengelolaan zakat tidak perlu dedikasi, maka dimungkinkan banyak akses yang akan terjadi. Seperti penyelewengan dana zakat untuk kepentingan pribadi, sasaran yang tidak tepat guna, tidak jujur, dan kurang amanah, krisis kepercayaan umat terhadap segala macam usaha penghimpunan dana umat Karena terjadi penyelewengan, adanya pola pandangan 
terhadap pelaksanaan zakat yang umumnya lebih antusias pada zakat fitrah, tidak seimbang dengan jumlah dana yang terhimpun dibanding dengan kebutuhan umat. Karena itu sifat jujur dan amanah menjadi bagian penting, sebab berkaitan dengan kepercayaan umat dan kebutuhan dalam sistem pengelolaan zakat yang professional. Keamanan dan kejujuran itu dapat diwujudkan dalam bentuk transparansi dan terbuka dalam penyampaian laporan pertanggungjawaban dalam setiap bulan atau tahun kepada pemerintah. (Duriyah, 2015, p. 64)

\section{Tabel 2}

Faktor Penghambat Dan Pendukung Pendistribusian Zakat di BAZNAS Kabupaten Kuantan Singingi

\begin{tabular}{|c|c|}
\hline $\begin{array}{c}\text { Faktor Penghambat } \\
\text { Pendistribusian } \\
\text { Zakat Di BAZNAS } \\
\text { Kabuapten Kuantan } \\
\text { Singingi }\end{array}$ & $\begin{array}{c}\text { Faktor } \\
\text { Pendukung } \\
\text { Pendistribusian } \\
\text { Zakat Di } \\
\text { BAZNAS } \\
\text { Kabupaten } \\
\text { Kuantan Singingi }\end{array}$ \\
\hline $\begin{array}{l}\text { 1. Terlambatnya data } \\
\text { pengusulan baik } \\
\text { dari } \\
\text { sekolah/mustabik. }\end{array}$ & $\begin{array}{l}\text { 1. Sumber daya } \\
\text { manusia yang } \\
\text { dimiliki sudah } \\
\text { sesuai dengan }\end{array}$ \\
\hline $\begin{array}{lr}\text { 2.Terlalu } & \text { banyaknya } \\
\text { peminat } & \text { Sementara } \\
\text { dana } & \text { yang } \\
\text { disalurkan } & \text { masih } \\
\text { terbatas. } & \end{array}$ & $\begin{array}{l}\text { bidang masing } \\
\text { masing staf di } \\
\text { BAZNAS } \\
\text { Kabupaten } \\
\text { Kuantan } \\
\text { Singingi. }\end{array}$ \\
\hline $\begin{array}{l}\text { 3. Tingginya nominal } \\
\text { permintaan } \\
\text { Mustabik dari yang } \\
\text { ditawarkan } \\
\text { 4.Kurangnya tenaga } \\
\text { dibidang }\end{array}$ & $\begin{array}{l}\text { 2. Fasilitas yang } \\
\text { sudah memadai } \\
\text { sehingga } \\
\text { memudahkan } \\
\text { dalam } \\
\text { melakukan } \\
\text { segala kegiatan }\end{array}$ \\
\hline
\end{tabular}

\begin{tabular}{|l|l|}
\hline Pendistribusian & dan pekerjaan \\
& di BAZNAS \\
& Kabupaten \\
& Kuantan \\
Singingi
\end{tabular}

Sumber: Olahan Penulis

\section{KESIMPULAN}

Berdasarkan hasil penelitian dan pembahasan yang telah peneliti lakukan pada BAZNAS Kabupaten Kuantan Singingi maka dapat disimpukan bahwa:

1. Manajemen pendistribusian dana zakat pendidikan pada BAZNAS Kabupaten Kuantan Singingi melalui program kuansing cerdas sudah sepenuhnya sesuai dengan fungsi-fungsi manajemen. Dalam proses manajemen yang dilakukan oleh BAZNAS Kabupaten Kuantan Singingi mulai dari perencanaan, pengorganisasian, pelaksanaan dan pengawasan. (a) perencanaan yang dilakukan dalam program kuansing cerdas mempertimbangkan manfaat yang ingin dicapai oleh BAZNAS Kabupaten Kuantan Singingi secara maksimal. Karena program kuansing cerdas ini ditujukan untuk siswa dan siswi yang masih menjalani proses pembelajaran disekolah. (b) pengorganisasian yang dilakukan oleh BAZNAS Kabupaten Kuantan Singingi yang terdiri dari perumusan kerja, pengelompokan kegiatan, penentuan tugas pokok, penetapan otoritas organisasi serta penetuan personalia. Hal ini melibatkan sumber daya yang ada dilingkungan BAZNAS Kabupaten Kuantan Singingi. (c) pelaksanaan yang dilakukan melalui penghimpunan zakat dari murakki yang berada di wilayah Kabupaten Kuantan Singingi melalui UPZ ataupun tidak. Untuk kemudian disalurkan kepada mustabik yang berhak menerimanya dalam 
hal ini adalah mereka penerima bantuan pendidikan di setiap masing-masing sekolah. (d) pengawasan yang dilakukan oleh BAZNAS Kabupaten Kuantan Singingi dalam pendistribusian zakat pendidikan ini bahwa dana yang disalurkan dari BAZNAS kepada penerima bantuan besarnya sesuai dengan yang disalurkan. pembagian dana zakat pendidikan tersebut diberiakan dalam bentuk uang tunai atau diberikan dalam bentuk potongan hutang disekolah.

2. Faktor penghambat pendistribusian zakat di BAZNAS Kabupaten Kuantan Singingi terdapat beberapa hambatan yang dihadapi antara lain: (a) Terlambatnya data pengusulan baik dari sekolah/mustahik. (b) terlalu banyaknya peminat Sementara dana yang disalurkan masih terbatas. (c) tingginya nominal permintaan Mustahik dari yang ditawarkan. (d) kurangnya tenaga dibidang Pendistribusian. Faktor pendukung pendistribusian zakat di BAZNAS Kabupaten Kuantan Singingi yaitu terdapat beberapa faktor pendukung diantaranya: (a) Sumber daya manusia yang dimiliki sudah sesuai dengan bidang masing masing staf di BAZNAS Kabupaten Kuantan Singingi. (b) Fasilitas kerja sudah memadai, kemudian didukung oleh tenaga-tenaga yang ahli dan sudah terlatih dibidangnya. Dengan adannya tenaga yang ahli atau sumber daya yang sudah tertalih dibidangnya ini akan membuat suatu organisasi akan cepat dalam pencapai tujuannya.

\section{DAFTAR KEPUSTAKAAN}

Duriyah, Siti (2015). Manajemen Pendistribusian Zakat (Studi Kasus Pada LAZIZMU PDM Kota Semarang Skripsi. Program Studi Ilmu Ekonomi Islam Fakultas Ekonomi Dan Bisnis Islam: Universitas Islam Negeri Walisongo Semarang.
Mursyidi. (2003). akuntansi zakat kontemporer. Bandung: PT. Remaja Rosdakary.

Nisa, A. K. (2016). Manajemen Pengumpulan dan Pendistribusian Dana Zakat Infak dan Sedekah di Lembaga Amil Zakat, Infak, Sedekah Mesjid Agung (LAZIZMA) Jawa Tengah. Semarang: Universitas Islam Negeri Walisongo Semarang.

Salim, Nur.(2020). Manajemen Pendidtribusian Zakat Dalam Program Beasiswa Terpadu (Better) Di LAZIS Jawa Tengah Cabang Salatiga.Skripsi. Program Studi Manajmen Dakwah Fakutas Dakwah:IAIN Salatiga

SOP BAZNAS Kabupaten Kuantan Singingi Tahun 2020

PERBAZNAS No 03 Tahun 2018 Tentang Pendistribusian Zakat.

Undang-Undang no 23 tahun 2011 tentang pengelolaan zakat.

Wiradifa, Riyantama.(2017) Strategi Pendistribusian Zakat, Infak, Dan Sedekah (ZIS) DI Badan Amil Zakat Nasional (BAZNAS) Kota Tanggerang Selatan . Al-Tijari, Vol. 3 No. 1. Desember 2017

Wawancara dengan amil Drs.H. Chaidir Arifin, ketua BAZNAS Kabupaten Kuantan Singingi pada tanggal 11 Februari 2021

Wawancara dengan amil Ramli, bidang keuangan dan pelaporan pada tanggal 11 Februari 2021

Wawancara dengan amil Marketa, bidang pelaksana dan pendisribusian pada tanggal 11 Februari 2021). 